\title{
Entrepreneurial Universities Index: A Scale Development Study
}

\author{
Mahmut Tekin \\ Faculty of Administrative and Economics, Selçuk University, Turkey \\ E-mail: mahtekin@selcuk.edu.tr \\ Tahsin Geçkil (Corresponding author) \\ Faculty of Applied Sciences, Necmettin Erbakan University, Turkey \\ E-mail: tgeckil@konya.edu.tr \\ Özdal Koyuncuoğlu \\ Faculty of Applied Sciences, Necmettin Erbakan University, Turkey \\ E-mail: okoyuncuoglu@konya.edu.tr
}

Received: May 10, 2017 Accepted: June 6, 2017

doi:10.5296/ber.v7i2.11200

URL: https://doi.org/10.5296/ber.v7i2.11200

\begin{abstract}
The reflections of the understanding of neo-liberal education on higher education are observed to have transformed universities into student centered institutions aiming for an education consistent with global development, generating an entrepreneurial and creative human resource and accordingly developing consistent education programs. In this context, it attracts attention that measurements are conducted to determine whether universities have an entrepreneurial structure. Although these measurements have various objectives, the primary aim is to constitute a competitive, entrepreneurial and innovative university governance system that meets the expectations of all stakeholders and to maintain the development of this system. The presence of different measurement tools in this regard would be scientifically useful. Based on this view, the aim of this study is to develop a new index regarding university entrepreneurship. At the scale development stage, the Content Validity Index study, which is the first phase of the scale development process consisting of three phases and ten steps, was performed. At the first stage, the statements that could be included in the
\end{abstract}


measurement tool were created in accordance with the literature and the opinions of experts. The 145 statements composed at this stage were revised in terms of clearness and repetitions, and a draft form consisting of 52 items was obtained. This draft was sent to experts from the field and their opinions were asked. Following the expert opinions, the Content Validity Index (CVI) study was conducted and it was determined that 50 items were left on the candidate scale.

Keywords: Entrepreneurship, University Entrepreneurship, Entrepreneur-friendly Universities, Scale Development Study

\section{Introduction}

The proliferation and achievement of effective entrepreneurship, which plays an important role for economic, technological and social development and progress, to a large extent depends on discovering new entrepreneurial individuals. Recently, it has become more noticeable that entrepreneurship provides significant contributions to the creation of new work areas and the solution of employment problems. This has increased the importance of studies aimed at discovering potential entrepreneurs.

Universities are continuously affected by the socio-economic, socio-political and socio-cultural changes caused by globalization. This has brought about radical changes in the functions, responsibility areas, structures and processes of universities and their abilities for creating funds and their levels of perceiving their environments. This forces universities to respond and adapt to this change, and moreover to adopt the mission of guiding the change. One part of this mission has been to improve the awareness of universities regarding entrepreneurship.

The dissemination of an entrepreneurial culture at universities and affiliated institutions started to be discussed as an issue in our country in relatively recent times. Studies on the measurement of the effectiveness of policy measures for the dissemination of an entrepreneurial culture are also not yet adequate. The entrepreneurial university ranking method named as the Entrepreneurship and Innovativeness Index, which has been developed and implemented at the university level by TUBITAK under the management of the Ministry of Science, Industry and Technology, has been used since 2012.

The method was started to be developed in 2010, and included in this study by taking the opinion of various faculty members. With the index, the 50 most entrepreneurial and innovative universities of our country are determined. The index is expected to rank the universities based on their entrepreneurial and innovative performances, and contribute to the increase of entrepreneurship and innovation-oriented competition and to the development of the entrepreneurship ecosystem. Besides, with the Entrepreneurial and Innovative University Index, it is aimed to promote entrepreneurship and innovation activities at universities. In the process of forming the index, a pilot study comprising 16 universities was conducted in the period of April-May 2012. After the pilot study, an assessment meeting was held with the vice rectors of 16 universities and the index set was brought to its final form also with the contribution of the related public institutions. The first outcomes of the index, which was 
formed in consensus with the related parties, were shared with the public by the Ministry of Science, Industry and Technology in October 2012 and the index has been used in the same form since that time.

Although many faculty members refer to the importance of this study, they also express their hesitations. The important role of the issue of entrepreneurship in the economy and the society, and the criticisms of the faculty members regarding the interuniversity university entrepreneurship measurement model has led us to consider that this area needed to be researched and encouraged us to conduct a study on this topic.

Experts on entrepreneurship emphasize the importance of studies on measuring university entrepreneurship. When evaluating the Entrepreneurial University Index Model, it is necessary to perform evaluations by considering the different judicial systems of countries, structural differences, and regional characteristics, histories of the universities and the stages they passed through, and the development level of the countries. Moreover, it is also necessary to take into consideration the own conditions of each university and the differences and diversities among their practices. For this reason, a standard model is not stated when making reference to the entrepreneurial university model. The important role of entrepreneurship on the economy and the society has led us to think that more studies are needed to be conducted on university entrepreneurship measurement models and motivated us to study on this topic.

\subsection{Entrepreneurial University Model and Turkey}

When we examine the development achieved by entrepreneurial universities, we observe two different trends of value production activities. In the first of these two trends, universities conduct activities that will maintain the increase of entrepreneurial intentions and skills among the whole public starting from their students and including their staff. These serve as training and skill-building activities covering a large scope ranging from raising awareness to guiding individuals with entrepreneurial intentions. In the second of these trends, universities carry out activities that will create value (activities that improve and increase the qualities of products and services, and ultimately the production and presentation of these to the consumers) almost like a business organization. This second case is a structural transformation which is also represented through concepts such as 'intrapreneurship, corporate entrepreneurship, etc.' in the 'Entrepreneurship' literature. There are certain reasons that require this transformation in higher education. The tendencies of deregulation, privatization and liberalization, which are the outcomes of the 'Globalization' process, decrease the dependence on public funding and thus the role of the state in higher education, and necessitates universities to have more entrepreneurial and competitive structures with regard to the market (Altbach et al., 2009).

The number of students in higher education that increased with the increasing competition and transition to mass education in the 1990s in the world and in our country made public resources inadequate and forced the institutions to look for new resources. This competitive environment, which was something new for universities, led them to projects that provide external resources, cooperation with universities in different regions, opening new campuses 
in different cities and countries, international mobility of students and academicians, and to processes of incorporation that regard students as 'customers'. With the adaptation of the neo-liberal policies of some country governments such as the US to universities, it was also suggested that universities needed to be 'entrepreneurial' to create new resources (Küçükcan and Gür, 2009).

Rinne (2009) states the elements that activate universities on the way to become entrepreneurial as internal and external factors. The external factors are listed as (1) the formation of European Higher Education Area-EHEA, (2) demand for more autonomy, (3) international competition, and the internal factors are (1) traditional culture and administration mechanisms, (2) academic capitalism, (3) entrepreneurial activities, and (4) role of the university in the higher education system (Rinne, 2009, as cited in Sakınç and Bursalığ 1, 2012).

Entrepreneurial university model has followed a process that started with the consultancy services offered by the academic staff in the areas of industry and commerce at the investigative and innovative universities of the US such as MIT and Stanford at the end of the 19th century and today spread to European universities like Cambridge and Twente and developed through the formation of independent institutions working between the university and the industry and the assignment of new characteristics and functions to the university. Universities have been changing in the direction of providing an increase in regional, social and economic welfare through interacting with the industry without obstructing their traditional function of education and research (Odabaşı, 2006).

The efforts of universities to maintain an increase in welfare has carried them beyond being merely the elements of the market of thought. Today's universities have become competing institutions with the quality of their students and instructors, the resources they possess and provide, and their respectability in the public eye. The environment that surrounds universities has currently been evolving into an image of a market. The market in question creates a culture of management and enterprise that often conflicts with the traditional and academic culture and makes higher education institutions more competitive and more integrated with the industrial sector (Günay, 2007). Higher education institutions have been focusing on entrepreneurship for their new role of being able to support the national and regional increase of welfare.

The dissemination of entrepreneurship training activities at universities and thus the development of the entrepreneurial characteristics of individuals is also as important as the success of universities in gaining an entrepreneurial structure for the development of entrepreneurship (Yelkikalan et al., 2010). The first step for a university to develop its entrepreneurial characteristics is to measure the level of entrepreneurship in the current situation. The following steps are the assessment of the developments within the process and the creation of the roadmaps that will contribute to achieving the desired level.

\subsection{Aim}

The aim of the present study is to develop an index that evaluates the entrepreneurial and 
innovative potentials of universities and presents the entrepreneur-friendliness levels of universities. The first trend regarding university entrepreneurship was taken as base for our study. That is, the approach which suggests that the university conducts activities that maintains the increase of entrepreneurial intentions and skills among the whole public starting from their students and including their staff was adopted in our study. The development of entrepreneurial intentions and skills in these environments has been named with the term 'Entrepreneur-friendly University' in our study, which is aimed to be contributed to the literature.

\section{Method}

\section{Research Model}

A study of content validity, which is the first step of scale development, was conducted in this methodological research.

\subsection{Validity Study}

There are three primary criteria for testing the validity of a measurement tool (Tezbaşaran, 1996; Gözüm and Aksayan, 2003). These are;

1. Content validity

2. Construct validity

3. Criterion-related validity.

The validity study of the developed index was conducted based on the content validity explained below.

\subsection{Content Validity}

This is the stage at which the ability of the items to measure the characteristics that are aimed to be measured is determined. The comprehensiveness of the scale is generally tested by using the opinions of the experts on the topic of the scale and the related literature (Tezbaşaran, 1996). At this stage, the content validity study known as Lawshe's technique was employed (Lawshe, 1975). Lawshe's technique consists of the following 6 steps:

1. Constitution of the domain expert group

2. Preparation of the candidate scale form

3. Obtaining experts' opinions

4. Calculation of the content validity indexes regarding the items

5. Obtaining the content validity index of the scale

6. Constitution of the candidate scale form based on the content validity index.

At this first stage of the study, these 6 steps of content validity were implemented.

\subsection{Data Collection}

An item pool consisting of 145 items was created based on the literature review and the opinions of the domain experts to determine the statements to be included in the index (Grave et al., 2013; Tübitak, 2013a; Tübitak, 2013b). The obtained items were reviewed by the researchers, the repeated items were deleted and a draft measurement instrument of 52 items 
was obtained.

The draft scale was sent to 28 faculty members from the related field in Turkey through electronic mail to obtain expert opinions for content validity, and 13 of these faculty member experts replied back. The experts were asked to evaluate each statement that was planned to be included in the measurement tool and to give points between 1 and 5. In the evaluation that was asked to be performed regarding the applicability of each item for measuring the attribute aimed to be measured, 1 point is explained with the statement "by no means applicable", 2 points with "not applicable", 3 points with "applicable", 4 point with "very applicable", and 5 points with "completely applicable". The opinions of the experts who gave 3,4 , and 5 points to an item on the expert opinion form were regarded as "essential".

As the result of the expert evaluations, the Item Content Validity Index (I-CVI) was calculated for each of the 52 items. The content validity index is calculated by dividing the number of experts who indicated an item as "essential" (ng) to the total number of experts (N) (Polit and Beck, 2006).

Table 1. Minimum content validity index values that the items are required to have to be included in the scale

\begin{tabular}{cccc}
\hline Number of experts & Minimum value & Number of experts & Minimum value \\
\hline 5 & 0.99 & 13 & 0.54 \\
6 & 0.99 & 14 & 0.51 \\
7 & 0.99 & 15 & 0.49 \\
8 & 0.78 & 20 & 0.42 \\
9 & 0.75 & 25 & 0.37 \\
10 & 0.62 & 30 & 0.33 \\
11 & 0.59 & 35 & 0.31 \\
12 & 0.56 & $40+$ & 0.29 \\
\hline
\end{tabular}

If the CVI value for an item includes negative values or 0 , such items are eliminated at the first stage. Although the acceptable Item CVI values of the items to be included in the scale vary depending on the number of experts, this value is recommended to be not lower than .78 (Polit and Beck, 2006). Lawshe (1975) states the minimum CVI values that the items are required to have to be included in the scale as shown in Table 1. The items with a CVI value smaller than the one shown in Table 1 would not be included in the developed scale.

\subsection{Limitations of the Study}

The most important limitation of the present study is that the content validity stage, which is only the first stage of the scale development study, was conducted, but the other stages have not been completed yet. The statements presented in the study are limited to the time and place at which the study was conducted, the literature reviews of the researchers, and opinions of experts. 


\section{Findings}

In this study, 13 experts evaluated a total of 52 items, and the content validity index of each item was calculated (Table 2). The content validity index (CVI) calculated for each item in Table 2 was compared with the minimum value (0.54) in Table 1 depending on the number of experts, and the items with a value bigger than this minimum value were accepted (A). Accordingly, since the CVI values of 50 of the 52 items were bigger than the minimum value, the candidate scale form consisted of 50 items. The items were given their final shape by taking into consideration the suggestions of the experts for minor changes.

While the I-CVI values of the items included in the index varied between .62 and 1.0, the Scale Content Validity Index (S-CVI) for the entire scale was calculated as .82 (Table 2). An S-CVI of .80 or higher is stated as an acceptable value (Polit and Beck, 2006). Accordingly, the item and scale CVIs of the candidate measurement tool were at acceptable levels.

Table 2. Content validity index values of the items to be included in the scale depending on the number of experts

\begin{tabular}{|c|c|c|c|c|c|}
\hline Scale statements & $\mathbf{z}$ & $z^{n 00}$ & $\begin{array}{l}\text { ga } \\
\sum_{*}^{\prime \prime} \\
z\end{array}$ & $\sum_{\substack{* \\
*}}$ & 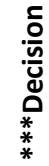 \\
\hline 1. Is there an entrepreneurship office/center at your university? & 13 & 13 & $13 / 13$ & 1.0 & A \\
\hline $\begin{array}{l}\text { 2. The number of projects your university received from } R \& D \text { and innovation } \\
\text { funding programs in the previous year }\end{array}$ & 13 & 12 & $12 / 13$ & .92 & A \\
\hline $\begin{array}{l}\text { 3. The amount of funding your university received from } R \& D \text { and innovation } \\
\text { funding programs in the previous year }\end{array}$ & 13 & 12 & $12 / 13$ & .92 & A \\
\hline $\begin{array}{l}\text { 4. The number of national and international science awards your university } \\
\text { received in the previous year }\end{array}$ & 13 & 10 & $10 / 13$ & .77 & A \\
\hline $\begin{array}{l}\text { 5. The number of } R \& D \text { and innovation projects conducted through } \\
\text { university-industry collaboration }\end{array}$ & 13 & 12 & $12 / 13$ & .92 & A \\
\hline $\begin{array}{l}\text { 6. The amount of funding received from } R \& D \text { and innovation projects } \\
\text { conducted through university-industry collaboration }\end{array}$ & 13 & 11 & $11 / 13$ & .85 & A \\
\hline $\begin{array}{l}\text { 7. The number of } \mathrm{R} \& \mathrm{D} \text { and innovation projects conducted through international } \\
\text { collaboration }\end{array}$ & 13 & 11 & $11 / 13$ & .85 & A \\
\hline $\begin{array}{l}\text { 8. The amount of funding received from international R\&D and innovation } \\
\text { collaborations }\end{array}$ & 13 & 11 & $11 / 13$ & .85 & A \\
\hline 9. The number of doctoral graduates at your university in the previous year & 13 & 9 & $9 / 13$ & .69 & A \\
\hline 10. The number of patent applications from your university in the previous year & 13 & 13 & $13 / 13$ & 1.0 & A \\
\hline $\begin{array}{l}\text { 11. The number of patent specifications received by your university in the } \\
\text { previous year }\end{array}$ & 13 & 12 & $12 / 13$ & .92 & A \\
\hline $\begin{array}{l}\text { 12. The number of utility model/industrial design documents received by your } \\
\text { university in the previous year }\end{array}$ & 13 & 12 & $12 / 13$ & .92 & A \\
\hline
\end{tabular}


13. The number of international patent applications from your university in the previous year

14. The number of international patent specifications received by your university in the previous year

15. The number of entrepreneurship stimulus programs your university applied for. How many of these are external stimulus programs?

16. The number of projects accepted by entrepreneurship stimulus programs

17. The number of projects that received an entrepreneurship award

18. The number of scientific publications from your university last year (general)

19. The number of citations of your university last year (general)

20. The number of academic staff/students in mobility in the previous year

21. Presence of a technology transfer office organization

22. The number of entrepreneurship, technology management and innovation management training/certificate programs offered outside the university

23. The number of active companies that the academic staff act as partners or own at techno-parks, business incubators, Technology Development Centers

24. The number of active companies that the students act as partners or own at techno-parks, business incubators, Technology Development Centers

25. The number of people employed by companies that the academic staff act as partners or own at techno-parks, business incubators, Technology Development Centers

26. Do you have units that provide support only in the area of entrepreneurship at your university?

27. The number of staff employed in the area of entrepreneurship at the units of your university (Faculty, Institute, School, Vocational School, Research Center)

28. Does your university have a roadmap regarding its innovation transfer strategy (including the targets, implementation areas and precautions)?

29. What other kinds of support is provided in the area of entrepreneurship alongside consultancy services? If there are any, please state (training, process monitoring/support, funding support, maintaining connections, providing infrastructure, etc.)

30. What is the total expenditure your university made on entrepreneurship in the previous year? (Salaries and other extra payments to the staff working in the area of entrepreneurship + equipment and consumable materials used for work 13 + support and training expenditures for prospective entrepreneurs + expenditures for the development of entrepreneurship, etc.)

31. In your opinion, what are your product and service advantage areas regarding entrepreneurship support that were effective last year apart from the known

\begin{tabular}{|l|l|l|l|l}
13 & 12 & $12 / 13$ & .92 & $\mathrm{~A}$ \\
\hline 13 & 12 & $12 / 13$ & .92 & $\mathrm{~A}$ \\
\hline 13 & 11 & $11 / 13$ & .85 & $\mathrm{~A}$
\end{tabular}

\begin{tabular}{|l|l|l|l|l|}
13 & 11 & $11 / 13$ & .85 & $\mathrm{~A}$ \\
\hline
\end{tabular}

\begin{tabular}{|l|l|l|l|l|l|}
\hline 13 & 10 & $10 / 13$ & .77 & $\mathrm{~A}$ \\
\hline
\end{tabular}

\begin{tabular}{l|l|l|l|l|}
13 & 8 & $8 / 13$ & .62 & $\mathrm{~A}$ \\
\hline
\end{tabular}

\begin{tabular}{l|l|l|l|l|l}
13 & 8 & $8 / 13$ & .62 & $\mathrm{~A}$
\end{tabular}

\begin{tabular}{l|l|l|l|l|l}
13 & 10 & $10 / 13$ & .77 & $\mathrm{~A}$
\end{tabular}

\begin{tabular}{l|l|l|l|l|l}
13 & 13 & $13 / 13$ & 1.0 & $\mathrm{~A}$
\end{tabular}

$\begin{array}{lllllll}13 & 12 & 12 / 13 & .92 & \mathrm{~A}\end{array}$

\begin{tabular}{|l|l|l|l|l}
13 & 10 & $10 / 11$ & .77 & $\mathrm{~A}$ \\
\hline
\end{tabular}


support and services of your university in the area of entrepreneurship?

32. The number of seminars, theoretical classes, practical classes, workshops on entrepreneurship (These values will be requested individually in the final index)

33. The number of student initiatives in the area of entrepreneurship (e.g. entrepreneurial student societies, Innovative student groups)

34. The number of entrepreneurship and idea competitions organized at your university last year

35. Has the final appraisal of the recognized entrepreneurships of the students who graduated last year and those who are active been carried out?

36. Are the guided entrepreneurships followed up afterwards?

37. What is the number of entrepreneurships introduced by graduate and active students of your university?

38. Do you have certificated entrepreneurship programs?

39. Is there sensitivity for corporate entrepreneurship (entrepreneurial culture)? If not, state the reasons. a) The area that the university focuses on is different $b$ ) Lack of financial resources c) Lack of know-how d) Other

40. Does your university offer extracurricular awareness raising activities on entrepreneurship?

41. How many times did your university (Entrepreneurship Coordination Office/Center, etc.) provide concrete Entrepreneurship Project Support last year?

42. What are your activities for enabling entrepreneurial awareness to take root at the institution?

43. How many of the academic units at your university have Entrepreneurship courses in their elective courses pool?

44. Is Entrepreneurship included on the university website (in the $1^{\text {st }}$ menu>high level, in the $2^{\text {nd }}$ menu>low level)?

45. The number of entrepreneurship projects consulted by your university in the previous year

46. Is your university member to the national or international corporate entrepreneurship networks? If yes, state to which ones.

47. The number of personnel that worked in the entrepreneurship support carried out within the previous year (Entrepreneurship center, Techno-polis, Techno-park, etc.)

48. What is the capacity of your university for providing consultancy services to prospective entrepreneurs (graduates and active students)? (the total time of service provided by qualified staff, mentors, etc. in hours)

49. The total time of consultancy services provided to prospective entrepreneurs 


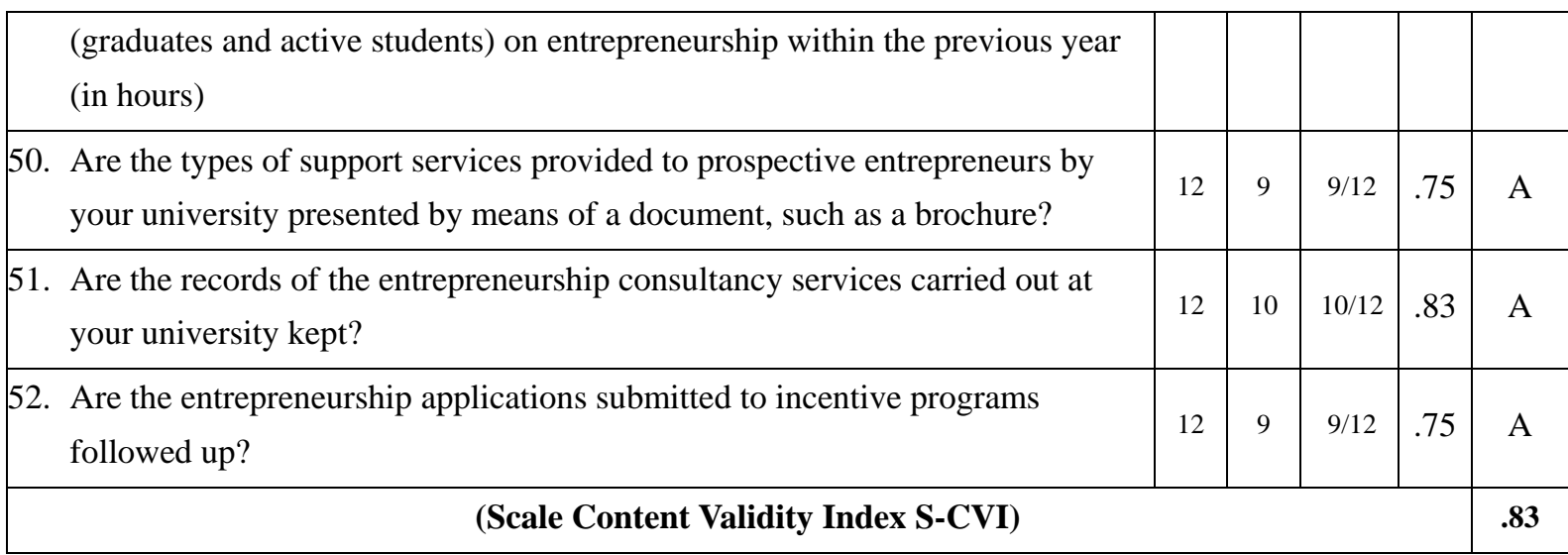

$* \mathbf{C V I}=$ Number of experts who indicated an item as essential (ng)/ Total number of experts (N)

**CVI: Content Validity Index Values

***Decision $\mathrm{A}=$ Accepted (0.54 and above), $\mathrm{R}=$ Rejected (Lawshe 1975)

Following the analysis of Table 2, two of the 52 statements were rejected based on the opinions of experts. Since the value of acceptance was taken as $0.62,50$ of the statements were accepted. According to 13 experts (table 1), the minimum admissible value should be 0.54 however our value was 0,62 as seen in Table 2 .

\section{Conclusion and Future Perspectives}

In the present study, which was conducted to develop a valid and reliable instrument for measuring the entrepreneurial and innovative potentials of universities, it was decided to include the 50 items given in Table 2 in the measurement tool as the result of the evaluation conducted to determine the statements that would appear in the index. Since the concepts of Entrepreneurship and Innovativeness are close in terms of meaning, it is thought that it would be more appropriate to name the index as Entrepreneurial Universities Index or Entrepreneur-friendly University Index, which would also emphasize the aim of the index, rather than Entrepreneurial and Innovative University Index.

The items that would be included in the Entrepreneurial Universities Index were determined in this study. In the following stages, the dimensions of the index and the weights of these dimensions will be determined by taking the local and foreign indexes into consideration. Finally, it is aimed to develop the index model by means of a pilot implementation.

The review of the entrepreneurial university models suggested for Turkey in the literature reveal the existence of various tendencies. One side of these tendencies is the approach that considers the university as an "enterprise" in the pure sense based on that universities directly enter the market and conduct profit-oriented activities (Özer, 2011:91). On the other side, the Entrepreneurial University is considered as a multifunctional structure that produces innovation, utilizes the opportunities, is prone to teamwork, can change its organizational structure to be successful, has a pioneering role in producing knowledge, can find resources other than those provided by the state, creates connections among the university, the state, and the industry, and can provide economic contribution (Odabaş1, 2008: 371). However, in 
the model which our study is based on, entrepreneurial university involves training and skill development activities that center students, but at the same time range to raising an awareness of entrepreneurship among its entire staff and stakeholders together with its students, and guiding the individuals with entrepreneurial intentions. No matter how you view it, the transformation of the universities in Turkey into the profile of entrepreneurial universities means a big journey for them. For the universities in Turkey, which are largely funded by public resources, being successful in this big journey is related not only to the definition of what kind of an entrepreneurial university model will be adopted but also to public expectations. Besides, the internal dynamics of the universities will affect this journey to a large extent.

\section{Acknowledgement}

This study consists of the pioneering data of a research project supported by the Scientific Research Projects Coordination Unit of Selçuk University. An early version consisting of preliminary data was presented as a paper at the IIBA- $6{ }^{\text {th }}$ International Interdisciplinary Business-Economics advancement Conference held between 9-13 May 2016 in Miami, Florida.

\section{References}

Altbach, P. G., Reisberg, L., \& Rumbley, L. E. (2009). Trends in global higher education: tracking an academic revolution. UNESCO 2009 World Conference on Higher Education, France. Retrieved from: http://unesdoc.unesco.org/images/0018/001831/183168e.pdf

Ekonomik Forum (2012). Girişimci ve yenilikçi üniversite endeksi. Retrieved from http://haber.tobb.org.tr/ekonomikforum/2012/11/042-045.pdf

Gözüm, S., \& Aksayan, S. (2003). Kültürlerarası ölçek uyarlaması için Rehber II: Psikometrik özellikler ve kültürlerarası karşılaştırma. Hemşirelik Araştırma Dergisi, 1(5), 3-14. http://hemarge.org.tr/ckfinder/userfiles/files/2003/2003-vol5-sayi1-65.pdf

Günay, D. (2007). Yirmibirinci yüzyilda üniversite, in C. C. Aktan (ed.) Değişim çağında yüksek ögrretim gobal trendler-paradigmal yönelimler), Yaşar Üniversitesi, İzmir: Birleşik Matbaacilik, pp. 77-88.

Grave, B., Hetze, P., \& Kanig, A. (2013). Gründungsradar 2013 - Wie hochschulen unternehmensgründungen fördern. Stifterverband für die deutsche Wissenschaft, Edition Stifterverband - Verwaltungsgesellschaft für Wissenschaftspflege mbH, Essen 2014.

Küçükcan, T., \& Gür, B. S. (2009). Türkiye’de yükseköğretim karşılaştırmalı bir analiz. Siyaset Ekonomi Ve Toplum Araştırmaları Vakfı, SETA.

Lawshe, C. H. (1975). A quantitative approach content validity. Personnel Psychology, 28, 563-575. https://doi.org/10.1111/j.1744-6570.1975.tb01393.x

Odabaşı, Y. (2006). Değişimin ve dönüşümün aracı olarak girişimci üniversite. Girişimcilik ve Kalkınma, 1(1), 87-104.

http://acikerisim.lib.comu.edu.tr:8080/xmlui/bitstream/handle/COMU/974/Yavuz_Odabasi_ Makale.pdf?sequence=1\&isAllowed=y 


\section{Macrothink}

Business and Economic Research ISSN 2162-4860 2017, Vol. 7, No. 2

Odabaş1, Y. (2008). Meslektaş girişimci üniversite ve yönetimi: Türk üniversiteleri için bir model önerisi. 2. Girişimcilik Kongresi, 370-378.

http://yavuzodabasi.blogspot.com.tr/2008/05/meslekta-giriimci-niversite-ve-ynetimi.html

Özer, Y. E. (2011). Model of entrepreneurial university and turkey. Uludă̆ Journal of Economy and Society, 30(2), 85-100.

http://www.acarindex.com/dosyalar/makale/acarindex-1423935829.pdf

Polit, D. F., \& Beck, C. T. (2006). The content validity index: Are you sure you know what's being reported? Critique and recommendations. Research in Nursing \& Health, 29, 489-497. https://doi.org/10.1002/nur.20147

Rinne, R. (2009). The changing faces of higher education and inclusion and exclusion: Nordic tunes. SANORD 2nd International Conference Inclusion and Exclusion in Higher Education, Rhodes University, Grahamstown, South Africa. Retrieved from http://www.sanord.uwc.ac.za

Sakınç, S., \& Bursalıoğlu, A. S. (2012). Yükseköğretimde küresel bir değişim: girişimci üniversite modeli. Yükseköğretim ve Bilim Dergisi, 2(2), 92-99.

http://higheredu-sci.beun.edu.tr/pdf/pdf_HIG_1564.pdf

Tezbaşaran, A. (1996). Likert tipi ölçek geliştirme kilavuzu. Psikologlar Derneği Yayınları. Ankara.

http://www.academia.edu/1288035/Likert_Tipi_\%C3\%961\%C3\%A7ek_Haz\%C4\%B1rlama_ $\mathrm{K} \% \mathrm{C} 4 \% \mathrm{~B} 1 \mathrm{lavuzu}$

Tübitak 2013a, http://www.tubitak.gov.tr/sites/default/files/gyue_2013_bilgi_notu.pdf, Retrieved on March 01, 2016.

Tübitak 2013b, http://www.tubitak.gov.tr/sites/default/files/gyue_2013_gosterge_seti.pdf, Retrieved on March 01, 2016.

Yelkikalan, N., Akatay, A., Yıldırım, H. M., Karadeniz, Y., Köse, C., Koncagül, Ö., \& Özer, E. (2010). Dünya ve Türkiye Üniversitelerinde Girişimcilik Eğitimi: Karşılaştırmalı Bir Analiz. KMÜ Sosyal ve Ekonomik Araştırmalar Dergisi, 12(19), 51-59.

http://dergi.kmu.edu.tr/userfiles/file/aralik2010/51-59.pdf

\section{Copyright Disclaimer}

Copyright for this article is retained by the author(s), with first publication rights granted to the journal.

This is an open-access article distributed under the terms and conditions of the Creative Commons Attribution license (http://creativecommons.org/licenses/by/3.0/). 